Review

\title{
The Relationship between Pneumocystis Infection in Animal and Human Hosts, and Climatological and Environmental Air Pollution Factors: A Systematic Review
}

Robert F. Miller ${ }^{1,2,3,4{ }^{*} \text {, Laurence Huang }}{ }^{5,6}$, Peter D. Walzer ${ }^{7}$

1. Centre for Clinical Research in Infection and Sexual Health, Institute for Global Health, University College London, London WC1E 6JB, UK; Email: robert.miller@ucl.ac.uk

2. Clinical Research Department, Faculty of Infectious and Tropical Diseases, London School of Hygiene and Tropical Medicine, London WC1E 7HT, UK

3. Bloomsbury Clinic, Mortimer Market Centre, Central \& North West London NHS Foundation Trust, London WC1E 6JB, UK

4. HIV Services, Royal Free London NHS Foundation Trust, London NW3 2QG, UK

5. Division of Pulmonary and Critical Care Medicine, Zuckerberg San Francisco General Hospital and Trauma Center, University of California, San Francisco, CA 94110, USA; Email: laurence.huang@ucsf.edu

6. HIV, Infectious Diseases, and Global Medicine Division, Zuckerberg San Francisco General Hospital and Trauma Center, University of California, San Francisco, San Francisco, CA 94110, USA

7. Department of Internal Medicine, University of Cincinnati, Cincinnati, OH 45267, USA; Email: peter.walzer1@gmail.com

* Correspondence: Robert F Miller; E-mail: robert.miller@ucl.ac.uk

Academic Editors: Andrés Moya, Enrique J. Calderón, and Luis Delaye

Special Issue: $\underline{\text { Pneumocystis: A Model of Adaptive Coevolution }}$

OBM Genetics

2018, volume 2, issue 4

doi:10.21926/obm.genet.1804045
Received: September 14, 2018

Accepted: October 19, 2018

Published: October 26, 2018

\section{Abstract:}

Background: Over the past decade, there has been rising interest in the interaction of Pneumocystis with the environment. This interest has arisen in part from the demonstration

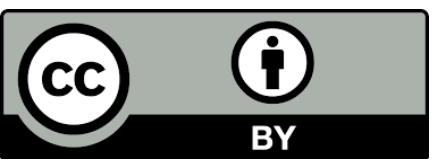

(C) 2018 by the author. This is an open access article distributed under the conditions of the Creative Commons by Attribution License, which permits unrestricted use, distribution, and reproduction in any medium or format, provided the original work is correctly cited. 
that environmental factors have important effects on the viability and transmission of microbes, including Pneumocystis. Environmental factors include climatological factors such as temperature, humidity, and precipitation, and air pollution factors including carbon monoxide, nitrogen dioxide, sulfur dioxide, and particulate matter.

Methods: We undertook a systematic review in order to identify environmental factors associated with Pneumocystis infection or PCP, and their effects on human and animal hosts.

Results: The systematic review found evidence of associations between Pneumocystis infection in animal and human hosts, and climatological and air pollution factors. Data from human studies infers that rather than a seasonal association, presentation with PCP appears to be highest when the average temperature is between 10 and $20^{\circ} \mathrm{C}$. There was evidence of an association with hospitalization with PCP and ambient air pollution factors, as well as evidence of an effect of air pollution on both systemic and bronchoscopic lavage fluid humoral responses to Pneumocystis. Interpretation of human studies was confounded by possible genetically-determined predisposition to, or protection from infection.

Conclusions: This systematic review provides evidence of associations between Pneumocystis infection in both animal and human hosts, and climatological and environmental air pollution factors. This information may lead to an improved understanding of the conditions involved in transmission of Pneumocystis in both animal and human hosts. Such knowledge is critical to efforts aimed at prevention.

\section{Keywords}

Pneumocystis; season; temperature; climate; environment; air pollution; detection

\section{Introduction}

Pneumocystis jirovecii is a fungus that continues to be an important cause of pneumonia (PCP) in the immunocompromised host and a major cause of death in humans [1]. It is estimated that there are more than 400,000 annual cases of PCP worldwide, with over 52,000 deaths per year [2]. Knowledge of the basic biology of Pneumocystis has long been limited by of the lack of a reliable and reproducible method of in vitro cultivation [3] but important insights have been gained from both animal and human studies. Pneumocystis organisms found in different hosts are morphologically indistinguishable but host species-specific [1]. Colonization of apparently healthy asymptomatic humans may provide a reservoir of $P$. jirovecii, and transmission of Pneumocystis to both susceptible and healthy persons may occur. However, the exact relationship is incompletely understood, and environmental reservoirs for the organism have also been suggested. Pneumocystis infection is acquired by inhalation, and the infective moiety is the cystic form [4] but the precise conditions for airborne transmission are unknown. Traditionally, PCP was thought to be the result of reactivation of latent infection acquired early in childhood, but molecular studies from PCP outbreaks demonstrate that PCP can also result from recent exposure in an at-risk host [5]. As a result, an improved understanding of the conditions involved in transmission is critical to efforts at prevention. 
Over the past decade, there has been rising interest in the interaction of Pneumocystis with the environment. This interest has arisen in part from the demonstration that environmental factors have important effects on the viability and transmission of microbes, including Pneumocystis. Studies have demonstrated an association between environmental factors and the risk of PCP as well as specific antibody responses against $P$. jirovecii. The environmental factors can broadly be divided into two groups: a) climatological factors such as temperature, humidity, and precipitation; and b) air pollution factors including carbon monoxide (CO), nitrogen dioxide $\left(\mathrm{NO}_{2}\right)$, sulfur dioxide $\left(\mathrm{SO}_{2}\right)$ and particulate matter [6]. We undertook this systematic review in order to identify specific environmental factors associated with Pneumocystis infection or PCP, and their effects on human and animal hosts. Our goal was to comprehensively review the published literature on this topic in order to gain insights and advance our understanding of this important human pathogen.

\section{Materials and Methods}

We sought to identify publications describing associations between environmental factors and detection of Pneumocystis in humans and animals, and with development and presentation with PCP. We first reviewed English-language published articles of Pneumocystis and PCP and associated climatological and air pollution factors for the period 01 January 1960 to the present day (30 June 2018) using PubMed (US National Library of Medicine). The following search terms were used: Pneumocystis [Title] + English [Language], then Human [MeSH], then one of the following MeSH: season, climate, air pollution, environment, geography, humidity, or temperature. In addition, we reviewed the references within each publication for additional articles. Since the first reports of human immunodeficiency virus (HIV)-associated PCP in the early 1980s, most cases of PCP in the literature have been described in the context of HIV infection.

The scope of the present study was increased to include animals studied in the wild, in slaughterhouses, and in research laboratories. The same time period was used and the following search terms were used in the literature search: Pneumocystis [Title] + English [Language], then, Animal [MeSH], then one of the following MeSH: season, climate, air pollution, environment, geography, humidity, or temperature. Inclusion of these animal studies was done in order to enhance the findings from human studies and to provide important insights that add to our understanding of studies in humans.

Studies identified by the search strategy were divided into three groups:

Group 1: animal studies. Group 2: human studies of HIV-infected and uninfected patients with PCP divided based on geographic location. Group 3: human studies of HIV-infected patients with PCP associated with ambient air pollutants.

Where specific climatological information (i.e., temperature and humidity/precipitation) was not described in a specific publication we used World Weather Online [7]. In addition, as this is a systematic review of previously published work, Ethics Committee/IRB approval was not required from any of the three centers involved in this work. 


\section{Results}

\subsection{Literature Search}

The PubMed literature search for the period 01 January 1960 through 30 June 2018 identified 74 unique full text articles. From these, 53 articles were excluded (after review of the full text by LH and RFM), as they were not relevant to the topic, or they were review articles that did not contain original data. In addition to the 21 remaining articles, 16 articles were identified by hand searching by the authors (LH and RFM). Additionally, the authors of some publications identified either by the MeSH search or via the "hand search" were contacted (by RFM) in order to obtain additional information not contained in their original published manuscript. Thus, in total 37 articles were identified and were included in the systematic review. Figure 1 shows the results of the literature search.

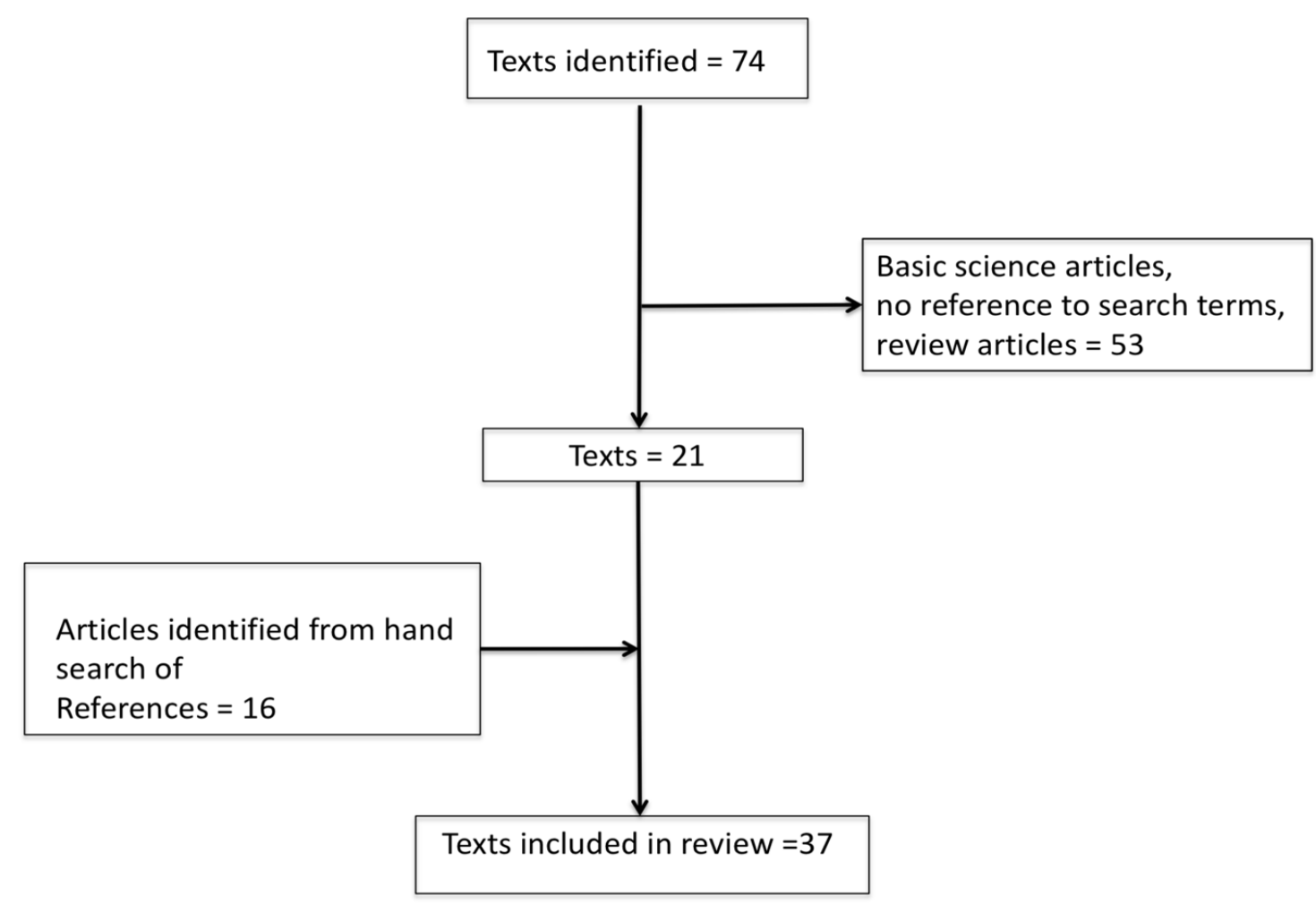

Figure 1 Results of literature search.

\subsection{Animal Studies Showing Associations between Detection of Pneumocystis and Seasonal and Environmental Factors}

Group 1. Eleven studies in animals (six from Europe, two from South America, two from Asia, and one from USA) were identified. Animal hosts were pigs (four studies), wild mouse species, shrew species, field voles, rats, hares, crab-eating macaques, and bats (each one study), (Table 1) [8-18]. Pneumocystis was detected in all of the animal species studied, using a range of techniques including Grocott silver staining, immunohistochemistry, and polymerase chain reaction (PCR). Using PCR, Pneumocystis was detected in as few as $4-5 \%$ of pigs in a slaughterhouse [17] to as many as $34.5 \%$ of crab-eating macaques living in a Primatology Center [12]. 
Table 1 Animal studies showing associations between detection of Pneumocystis spp and seasonal and environmental factors.

\begin{tabular}{|c|c|c|c|c|c|}
\hline Study authors & Year & Species & Location & Methods & Main findings \\
\hline $\begin{array}{l}\text { Šebek } \\
\text { Rosický } \\
\text { [8] }\end{array}$ & 1967 & $\begin{array}{l}\text { Shrew species (Sorex } \\
\text { araneus, Sorex alpinus, } \\
\text { and Neomys fodiens) }\end{array}$ & $\begin{array}{ll}\text { Multiple } & \text { rural } \\
\text { locations, } & \\
\text { Czechoslovakia. } & \\
\end{array}$ & $\begin{array}{l}\text { Grocott } \\
\text { silver } \\
\text { staining }\end{array}$ & $\begin{array}{l}\text { Pneumocystis identified in } 7 / 44(16 \%) \text { of shrews, only in } \\
\text { Spring, and not in Autumn. }\end{array}$ \\
\hline $\begin{array}{l}\text { Poelma \& } \\
\text { Broekhuizen } \\
\text { [9] }\end{array}$ & 1972 & Hare (Lepus europaeus) & $\begin{array}{l}\text { Research Institute of } \\
\text { Nature Management, } \\
\text { Arnhem, Netherlands. }\end{array}$ & $\begin{array}{l}\text { Grocott } \\
\text { silver } \\
\text { staining }\end{array}$ & $\begin{array}{l}\text { Pneumocystis identified in } 75 / 437(17 \%) \text { of hares, most } \\
\text { commonly identified during the period September to } \\
\text { December. }\end{array}$ \\
\hline $\begin{array}{l}\text { Shiota, } \\
\text { Kurimoto \& } \\
\text { Yoshida } \\
\text { [10] }\end{array}$ & 1986 & $\begin{array}{l}\text { Wild mouse species } \\
\text { (Apodemus speciosus, } \\
\text { Apodemus argenteus, } \\
\text { Microtus montebelli, } \\
\text { Mus musculus) }\end{array}$ & 6 localities, Japan. & $\begin{array}{l}\text { Grocott } \\
\text { silver } \\
\text { staining }\end{array}$ & $\begin{array}{l}\text { Pneumocystis detected in } 11 / 142(7.7 \%) \text { of Apodemus } \\
\text { speciosus; higher detection rate in Winter-Spring than in } \\
\text { Summer-Autumn. }\end{array}$ \\
\hline $\begin{array}{l}\text { Laakkonen, et } \\
\text { al } \\
{[11]}\end{array}$ & 1999 & $\begin{array}{l}\text { Field vole } \text { (Microtus } \\
\text { agrestis) \& Common } \\
\text { shrew (Sorex araneus) }\end{array}$ & $\begin{array}{l}\text { Rural Central (Luhanka) } \\
\text { and Southern (Evo) } \\
\text { Finland. }\end{array}$ & $\begin{array}{l}\text { Grocott } \\
\text { silver } \\
\text { staining }\end{array}$ & $\begin{array}{l}\text { Highest rates of Pneumocystis detection in both Microtus } \\
\text { agrestis and Sorex araneus seen in November. }\end{array}$ \\
\hline $\begin{array}{l}\text { Demanche, et } \\
\text { al } \\
{[12]}\end{array}$ & 2003 & $\begin{array}{l}\text { Crab-eating macaque } \\
\text { (Macaca fascicularis) }\end{array}$ & $\begin{array}{l}\text { Primatology Center, } \\
\text { Strasburg, France. }\end{array}$ & PCR & $\begin{array}{l}\text { Detection of Pneumocystis in } 166 / 481 \text { ( } 34.5 \%) \text { macaques: } \\
\text { higher detection rate associated with mean precipitation } \\
\text { rates. }\end{array}$ \\
\hline $\begin{array}{l}\text { Icenhour, et al } \\
\text { [13] }\end{array}$ & 2006 & $\begin{array}{l}\text { Brown Norway \& Long } \\
\text { Evans rats }\end{array}$ & $\begin{array}{l}\text { Laboratory facility, } \\
\text { Cincinnati, USA. }\end{array}$ & PCR & $\begin{array}{l}\text { Higher relative humidity associated with predominance of } \\
P \text {. carinii, higher temperatures associated with mixed } \\
\text { infections of } P \text {. carinii and } P \text {. wakefieldiae and lower } \\
\text { temperature associated with predominance of } P \text {. } \\
\text { wakefieldiae. }\end{array}$ \\
\hline $\begin{array}{l}\text { Sanches, et al } \\
\text { [14] }\end{array}$ & 2007 & Pigs & $\begin{array}{l}\text { Slaughterhouses, in Rio } \\
\text { Grande do Sul, and } \\
\text { Mato Grosso, Brazil. }\end{array}$ & $\begin{array}{l}\text { Grocott } \\
\text { silver } \\
\text { staining } \\
\text { Immunohi }\end{array}$ & $\begin{array}{l}\text { Pneumocystis detected in } 208 / 546 \text { (36.9\%) of pigs } \\
\text { slaughtered in February-March (summer). Detection rate } \\
\text { higher (39.9\%) in slaughterhouse with a lower average } \\
\text { temperature (Rio Grande do Sul: } 23^{\circ} \mathrm{C} \text { ) than in Mato }\end{array}$ \\
\hline
\end{tabular}




\begin{tabular}{|c|c|c|c|c|c|}
\hline & & & & $\begin{array}{l}\text { sto- } \\
\text { chemistry }\end{array}$ & Grosso slaughterhouse $\left(27^{\circ} \mathrm{C}\right)$. \\
\hline $\begin{array}{l}\text { Kim, et al } \\
{[15]}\end{array}$ & 2011 & Pigs & $\begin{array}{l}\text { Farms on Jeju Island, } \\
\text { Korea. }\end{array}$ & $\begin{array}{l}\text { Immunohi } \\
\text { sto- } \\
\text { chemistry }\end{array}$ & $\begin{array}{l}\text { Pneumocystis detected in } 39 / 172 \text { ( } 22.7 \%) \text { of pigs. More } \\
\text { commonly detected in cold season (December-March: } \\
\text { temperature } 8-9^{\circ} \mathrm{C} \text { ), than in hot season (June-September: } \\
\text { temperature } 21-23^{\circ} \mathrm{C} \text { ). } \\
\text { Detection of Pneumocystis associated with PCV2 and } \\
\text { PRRSV infection; in } 32 / 139(23 \%) \text { virus positive, and in } \\
4 / 28(14 \%) \text { of virus negative pigs. }\end{array}$ \\
\hline $\begin{array}{l}\text { Akbar, et al } \\
{[16]}\end{array}$ & 2012 & $\begin{array}{l}\text { Bats (New World and } \\
\text { Old World } \\
\text { microchiropters and Old } \\
\text { World megachiropters) }\end{array}$ & $\begin{array}{l}\text { New World (Mexico, } \\
\text { Guyana, and Argentina } \\
\text { wild bats and Old } \\
\text { World (France) wild } \\
\text { and captive bat } \\
\text { colonies. }\end{array}$ & PCR & $\begin{array}{l}\text { Pneumocystis identified in lungs of } 71 \text { of } 216 \text { (32.9\%) of } 19 \\
\text { bat species. More commonly detected in smaller, } \\
\text { sedentary and crowded bat colonies. Also in colonies at } \\
<800 \text { m elevation. No association with geographical (cave) } \\
\text { temperature or relative humidity. }\end{array}$ \\
\hline $\begin{array}{l}\text { Esgalhado, et } \\
\text { al } \\
{[17]}\end{array}$ & 2013 & Pigs & $\begin{array}{l}\text { Slaughterhouses in the } \\
\text { Lisbon and Tagus } \\
\text { valley, Portugal. }\end{array}$ & PCR & $\begin{array}{l}\text { Pneumocystis detected in } 14 / 215 \text { ( } 7 \% \text { ) of pigs. Detection } \\
\text { rates higher in pigs raised in Center and Algarve regions } \\
(10-13 \%) \text {, than in pigs from Lisbon and Alentejo regions (4- } \\
5 \%) \text {. No association with median temperature; association } \\
\text { with extremely low and high precipitation rates. Detection } \\
\text { more likely in semi-intensively farmed pigs (10\%), than in } \\
\text { intensively farmed pigs (5\%) }\end{array}$ \\
\hline $\begin{array}{l}\text { Weissenbache } \\
\text { r-Lang, et al } \\
{[18]}\end{array}$ & 2016 & Pigs & $\begin{array}{l}\text { Institute of Pathology } \\
\text { and } \quad \text { Forensic } \\
\text { Veterinary Medicine, } \\
\text { Vienna, Austria. }\end{array}$ & ISH/PCR & $\begin{array}{l}110 \text { Pneumocystis positive pigs with pneumonia; many } \\
\text { also had viral (PCV2, PRRSV, TTSuV1, TTSuV2), and/or } \\
\text { bacterial (B. bronchiseptica, } P \text {. multocida, M. } \\
\text { hyopneumoniae) infection. 79\% of moderate and severe } \\
\text { Pneumocystis seen in Winter-Spring (December-May). }\end{array}$ \\
\hline
\end{tabular}

Key: $\mathrm{PCR}=$ polymerase chain reaction; ISH = in situ hybridization; PCV2 = porcine circovirus type 2; PRRSV = porcine reproductive and respiratory syndrome virus; TTSuV1, TTSuV2 = torque teno sus virus type 1 and 2. 
The main findings were that in eight of the 11 studies there was a clear seasonal variation in detection of Pneumocystis among different hosts, in their natural surroundings [8, 9, 10, 11, 14, 15, $17,18]$. In the study of macaques housed in a Primatology Center, detection was associated with mean precipitation, and in the study of rats in a laboratory facility, temperature and humidity had a clear influence on the predominance of different types of Pneumocystis. Finally, the study of bats in both captive and wild environments showed no association between detection of Pneumocystis and either temperature or humidity, but an association with smaller, crowded sedentary colonies at altitudes below $800 \mathrm{~m}$ above sea level.

\subsection{Human Studies Showing Associations between Pneumocystis and Seasonal and Environmental Factors}

Group 2. Twenty-four studies in HIV-infected and uninfected patients with PCP were identified and were divided, based on geographic location. Seven studies were from USA, two from South America, 11 from Northern Europe, three from Southern Europe, and one from Australia, (Table 2) $[6,19-41]$. These studies were a mixture of prospective and retrospective clinical or laboratory (including autopsy) studies and were national, multi-center or single center in their design. Two studies were done in infants, the remaining 22 studies were done in adults. Among the adult studies 19 included only HIV-infected adults, two included HIV-infected and uninfected adults, and one included HIV-uninfected adults with underlying rheumatologic conditions. In the two studies of infants, subjects were HIV-uninfected [19-41].

The main findings were that in 18 studies in adults there was evidence of a seasonal and/or climatological association and presentation with PCP, or detection at autopsy and two studies showed no such association but noted clustering of cases of PCP by Zip Code, and another identified that time spent outdoors was associated with risk of PCP. In the remaining two studies there was no apparent seasonal or climatologic association with development of PCP. However, both studies showed an apparent ethnic predisposition, with patients of black African origin being at reduced risk of developing PCP compared to patients who were of Western origin (Table 2). Both studies in infants showed a seasonal variation either in detection of $P$. jirovecii at autopsy, or variation in antibody responses to Pneumocystis major surface antigen components. 
Table 2 Human studies showing associations between Pneumocystis and seasonal and environmental factors.

\begin{tabular}{|c|c|c|c|c|}
\hline $\begin{array}{l}\text { Region/ Study } \\
\text { authors }\end{array}$ & Year & Location & Methods & Main findings \\
\hline \multicolumn{5}{|l|}{ USA } \\
\hline $\begin{array}{l}\text { Navin, et al } \\
{[21]}\end{array}$ & 2000 & $\begin{array}{l}\text { Atlanta, } \\
\text { Georgia }\end{array}$ & $\begin{array}{l}\text { Two centre single city } \\
\text { retrospective cohort study. }\end{array}$ & $\begin{array}{l}\text { PCP associated with outdoor activities (gardening, hiking or } \\
\text { camping). }\end{array}$ \\
\hline $\begin{array}{l}\text { Morris, et al } \\
{[24]}\end{array}$ & 2004 & $\begin{array}{l}\text { MACS cohort } \\
\text { Four US cities }\end{array}$ & $\begin{array}{l}\text { Retrospective cohort study } \\
\text { of patients who had } \\
\text { necropsy. PCR detection of } \\
\text { P. jirovecii. }\end{array}$ & $\begin{array}{l}\text { Rates of colonization (determined by PCR) greater in cigarette } \\
\text { smokers. Detection rates higher in Chicago and Pittsburgh } \\
(70.4 \% \text { and } 61.5 \%) \text { than in Baltimore and Los Angeles ( } 42.3 \% \text { and } \\
16 \%) \text {. }\end{array}$ \\
\hline
\end{tabular}




\begin{tabular}{|c|c|c|c|c|}
\hline $\begin{array}{l}\text { Djawe, et al } \\
{[6]}\end{array}$ & 2013 & $\begin{array}{l}\text { San } \\
\text { Francisco, } \\
\text { California }\end{array}$ & Single centre cohort study. & $\begin{array}{l}\text { Seasonal variation in hospitalization with PCP; peak in summer } \\
\text { (June-August). }\end{array}$ \\
\hline \multicolumn{5}{|l|}{ South America } \\
\hline $\begin{array}{l}\text { Vargas, et al } \\
{[25]}\end{array}$ & 2005 & $\begin{array}{l}\text { Santiago, } \\
\text { Chile }\end{array}$ & $\begin{array}{ll}\text { Autopsy study, } & \text { two } \\
\text { children's hospitals. } & \text { PCR } \\
\text { detection of } P \text {. jirovecii. } & \end{array}$ & $\begin{array}{l}\text { P. jirovecii DNA detected in } 51.7 \% \text { of immune competent infants } \\
\text { dying in the community and in } 20 \% \text { dying in hospital. Seasonal } \\
\text { variation in detection: } 53 \% \text { in Winter (June - August) when } \\
\text { maximum temperature }=16-18^{\circ} \mathrm{C} \text {. and } 30 \% \text { in Autumn (March - } \\
\text { May) when maximum temperature }=20-28^{\circ} \mathrm{C} \text {. }\end{array}$ \\
\hline $\begin{array}{l}\text { Djawe, et al } \\
{[26]}\end{array}$ & 2010 & $\begin{array}{l}\text { Santiago, } \\
\text { Chile }\end{array}$ & Prospective cohort study. & $\begin{array}{l}\text { Seasonal variation in serum antibody titers to } P \text {. jirovecii among } \\
\text { immune competent infants. MsgA antibody titers highest in } \\
\text { Spring (September - November) and lowest in Autumn (March- } \\
\text { May) MsgC titers highest in Summer (December - February) and } \\
\text { Winter (June - August) }\end{array}$ \\
\hline \multicolumn{5}{|l|}{ Northern Europe } \\
\hline $\begin{array}{l}\text { Setnes \& Genner } \\
\text { [27] }\end{array}$ & 1986 & $\begin{array}{l}\text { Copenhagen, } \\
\text { Denmark }\end{array}$ & Two hospital autopsy study. & $\begin{array}{l}\text { Pneumocystis identified in } 83 / 1762 \text { (4.7\%) of autopsies at } \\
\text { Righospitalet and Finseninstituttet Hospitals 1979-1984. Lower } \\
\text { detection of Pneumocystis observed in } 1981 \text { corresponded with } \\
\text { low temperature, low vapor pressure, and low humidity. Higher } \\
\text { rate of detection in } 1982-3 \text { corresponded with higher average } \\
\text { temperature and vapor pressure. }\end{array}$ \\
\hline $\begin{array}{l}\text { Miller, Grant \& } \\
\text { Foley } \\
{[28]}\end{array}$ & 1992 & London, UK & $\begin{array}{l}\text { Single centre retrospective } \\
\text { cohort study. }\end{array}$ & $\begin{array}{l}\text { Seasonal variation in PCP: highest in June-July and September, } \\
\text { following periods with low rainfall and temperatures }<13^{\circ} \mathrm{C} \text {. }\end{array}$ \\
\hline $\begin{array}{l}\text { Vanhems, Hirschel } \\
\text { \& Morabia }\end{array}$ & 1992 & $\begin{array}{l}\text { Geneva, } \\
\text { Switzerland }\end{array}$ & $\begin{array}{l}\text { Single centre retrospective } \\
\text { cohort study. }\end{array}$ & $\begin{array}{l}\text { Seasonal variation in } \mathrm{PCP} \text { cases: highest in June - September. } \\
\text { Seasonal variation no longer observed after introduction of PCP }\end{array}$ \\
\hline
\end{tabular}


OBM Genetics 2018; 2(4), doi:10.21926/obm.genet.1804045

\begin{tabular}{|c|c|c|c|c|}
\hline$[29]$ & & & & prophylaxis. \\
\hline $\begin{array}{l}\text { Lundgren, et al } \\
\text { [30] }\end{array}$ & 1995 & $\begin{array}{l}\text { Copenhagen, } \\
\text { Denmark }\end{array}$ & $\begin{array}{l}\text { Multicenter prospective } \\
\text { study in Northern, Central } \\
\text { and Southern Europe. }\end{array}$ & $\begin{array}{l}\text { Incidence of PCP higher in cooler climates (Northern Europe), } \\
\text { compared with Central or Southern Europe. }\end{array}$ \\
\hline $\begin{array}{l}\text { Delmas, et al } \\
\text { [31] }\end{array}$ & 1995 & Paris, France & $\begin{array}{l}\text { Multicenter retrospective } \\
\text { study in eight European } \\
\text { countries and in } \\
\text { Amsterdam, Netherlands. }\end{array}$ & $\begin{array}{l}\text { Incidence of AIDS-defining PCP higher in Germany, Switzerland, } \\
\text { and UK (Northern/Central Europe), and lowest in Portugal and } \\
\text { Italy (Southern Europe). }\end{array}$ \\
\hline $\begin{array}{l}\text { Del Amo, et al } \\
\text { [32] }\end{array}$ & 1998 & London, UK & $\begin{array}{l}\text { Eleven center retrospective } \\
\text { cohort study. }\end{array}$ & $\begin{array}{l}\text { PCP was presenting AIDS-defining condition in } 52 / 313(17 \%) \text { of } \\
\text { black Africans, compared with } 52 / 314 \text { (34\%) of non-Africans } \\
\text { living in London. }\end{array}$ \\
\hline $\begin{array}{l}\text { Lubis, et al } \\
\text { [33] }\end{array}$ & 2003 & London, UK & $\begin{array}{l}\text { Single centre retrospective } \\
\text { cohort study. }\end{array}$ & $\begin{array}{l}\text { Variation in monthly incidence of PCP: highest in January (16.9\%) } \\
\text { associated with low monthly rainfall ( }<35 \mathrm{~mm} / \text { month). January } \\
\text { peak more prominent in some years and not evident in other } \\
\text { years. Other peaks in April }(9.8 \%) \text { and September }(9.6 \%) \text { not } \\
\text { associated with rainfall. }\end{array}$ \\
\hline $\begin{array}{l}\text { Miller, et al } \\
\text { [34] }\end{array}$ & 2007 & London, UK & $\begin{array}{l}\text { Single centre retrospective } \\
\text { cohort study. Genotyping of } \\
P \text {. jirovecii isolates at } \mathrm{mt} \\
\text { LSU rRNA locus. }\end{array}$ & $\begin{array}{l}\text { Association between Genotype } 2 \text { and mixed genotypes, and } \\
\text { season/month: peaks in June - July, and May - June and } \\
\text { September, respectively. No association between temperature, } \\
\text { or rainfall and specific genotypes. }\end{array}$ \\
\hline $\begin{array}{l}\text { Walzer, et al } \\
\text { [35] }\end{array}$ & 2008 & London, UK & $\begin{array}{l}\text { Single centre retrospective } \\
\text { cohort study. }\end{array}$ & $\begin{array}{l}\text { Seasonal variation in presentation of PCP over a } 21 \text { year period: } \\
\text { highest in summer (June - August; } 29.8 \% \text { ) and lowest in winter } \\
\text { (December - February; } 21.9 \% \text { ). }\end{array}$ \\
\hline $\begin{array}{l}\text { Sing, et al } \\
{[36]}\end{array}$ & 2009 & $\begin{array}{l}\text { Munich, } \\
\text { Germany }\end{array}$ & Single centre cohort study. & $\begin{array}{l}\text { Seasonal variation in cases of PCP: peak in summer (May - } \\
\text { August). Mean temperature (but not rainfall or wind strength) } \\
\text { associated with incidence of PCP. }\end{array}$ \\
\hline
\end{tabular}




\begin{tabular}{|c|c|c|c|c|}
\hline $\begin{array}{l}\text { Schoffelen, et al } \\
\text { [37] }\end{array}$ & 2013 & Netherlands & $\begin{array}{l}\text { ATHENA national } \\
\text { observational cohort study. }\end{array}$ & $\begin{array}{l}\text { PCP occurred less frequently in patients originating from sub- } \\
\text { Saharan Africa compared to patients of Western origin (Western } \\
\text { Europe, New Zealand, Australia); adjusted Odds Ratio }=0.21 \\
(0.15-0.29) \text {. }\end{array}$ \\
\hline \multicolumn{5}{|l|}{ Southern Europe } \\
\hline $\begin{array}{l}\text { Varela, et al } \\
\text { [38] }\end{array}$ & 2004 & Seville, Spain & $\begin{array}{l}\text { Single centre cohort study. } \\
\text { HIV-positive and HIV- } \\
\text { uninfected patients with } \\
\text { PCP. }\end{array}$ & $\begin{array}{l}\text { Inverse correlation between incidence of PCP and mean ambient } \\
\text { temperature. Highest number of cases in winter (January-March, } \\
\text { with peak in February) when mean minimum temperature was } \\
7-9.7^{\circ} \mathrm{C} \text { (and average temperature was } 10-16.5^{\circ} \mathrm{C}^{*} \text { ). No } \\
\text { association with humidity. }\end{array}$ \\
\hline $\begin{array}{l}\text { Calderon, et al } \\
\text { [39] }\end{array}$ & 2004 & $\begin{array}{l}\text { Anadalusia, } \\
\text { Spain }\end{array}$ & $\begin{array}{l}\text { Thirty two public hospitals } \\
\text { in southern Spain. HIV- } \\
\text { positive and HIV-uninfected } \\
\text { patients with PCP. }\end{array}$ & $\begin{array}{l}\text { Seasonal variation in PCP: highest in winter (December - } \\
\text { February: } 30.5 \% \text { of all cases), compared with spring }(23.9 \%) \text {, } \\
\text { summer }(23.7 \%) \text {, and autumn ( } 21.9 \%) \text {. Additional peak in May. }\end{array}$ \\
\hline $\begin{array}{l}\text { Alvaro-Meca, et al } \\
\text { [39] }\end{array}$ & 2015 & Spain & $\begin{array}{l}\text { Retrospective national } \\
\text { study of hospitalized HIV- } \\
\text { positive patients with PCP. }\end{array}$ & $\begin{array}{l}\text { Most cases of PCP occurred in winter (December - February), } \\
\text { fewest in summer (June - August), corresponding to lowest (10- } \\
20^{\circ} \mathrm{C} \text { ) and highest temperatures, respectively. }\end{array}$ \\
\hline \multicolumn{5}{|l|}{ Australia } \\
\hline $\begin{array}{l}\text { Tadros, et al } \\
\text { [40] }\end{array}$ & 2017 & $\begin{array}{l}\text { Melbourne, } \\
\text { Australia }\end{array}$ & $\begin{array}{l}\text { Retrospective single center } \\
\text { study of patients with } \\
\text { systemic autoimmune } \\
\text { rheumatic disease. }\end{array}$ & $\begin{array}{l}\text { PCP most commonly presented in Autumn (March - May) when } \\
\text { average temperature was } 13.2-20^{\circ} \mathrm{C} \text {; no cases occurred in } \\
\text { Winter (June - August) when average temperature was 10- } \\
12^{\circ} \mathrm{C}^{*} \text {. }\end{array}$ \\
\hline
\end{tabular}

Key: MACS = Multi-center AIDS cohort study; MSM = men who have sex with men; PCP = Pneumocystis jirovecii pneumonia; CDC = Centers for Disease Control and Prevention; ATHENA = AIDS Therapy Evaluation in the Netherlands; Msg = major surface glycoprotein; PCR = polymerase chain reaction; $\mathrm{mt}$ LSU rRNA $=$ mitochondrial large subunit ribosomal RNA. *data from World Weather Online [7]. 


\subsection{Human Studies Showing Associations between Pneumocystis and Ambient Air Pollution Factors}

Group 3. Four studies (three from USA, one from Spain) reported the impact of ambient air pollution factors among HIV-infected adult patients hospitalized with PCP (Table 3) [6, 40, 42, 43]. Of note two of these four studies are also included in Group $2[6,42]$. The San Francisco studies were single-center, prospective studies while the study from Spain was a national study.

The main findings were that one study showed elevated levels of $\mathrm{NO}_{2}, \mathrm{PM}_{10}$ and ozone in ambient air were associated with increased risk of hospitalization with PCP [40], and in another $\mathrm{SO}_{2}$, was associated with increased risk of hospitalization, but the risk was attenuated by elevated CO levels [6]. Two further studies that examined serologic responses in hospitalized patients with $\mathrm{PCP}$, and showed elevated $\mathrm{NO}_{2}$, and $\mathrm{PM}_{10}$ were independently associated with impaired IgM responses to $P$. jirovecii major surface glycoprotein (Msg) constructs in serum [42], and that there was an impaired IgA response to $P$. jirovecii Msg in bronchoscopic lavage (BAL) fluid that was associated with increased ambient ozone exposure. Additionally, increased BAL fluid IgA responses were associated with increased ambient $\mathrm{NO}_{2}$ exposure [43] (Table 3). 
Table 3 Human studies showing associations between Pneumocystis and ambient air pollution factors.

\begin{tabular}{|c|c|c|c|c|}
\hline Study authors & Year & Location & Methods & Main findings \\
\hline $\begin{array}{l}\text { Djawe, et al } \\
{[6]}\end{array}$ & 2013 & $\begin{array}{l}\text { San } \\
\text { Francisco, } \\
\text { USA }\end{array}$ & $\begin{array}{l}\text { Single center prospective cohort study of } \\
\text { hospitalised HIV-infected patients with } \\
\text { PCP. Climatologic and air pollution data. }\end{array}$ & $\begin{array}{l}\text { Increases in } \mathrm{SO}_{2} \text { levels associated with presentation with PCP. } \\
\text { Effect of } \mathrm{SO}_{2} \text { attenuated by rises in CO levels. }\end{array}$ \\
\hline $\begin{array}{l}\text { Blount, et al } \\
{[42]}\end{array}$ & 2013 & $\begin{array}{l}\text { San } \\
\text { Francisco, } \\
\text { USA }\end{array}$ & $\begin{array}{l}\text { Single center prospective cohort study of } \\
\text { hospitalised HIV-infected patients with } \\
\text { PCP. Climatologic and air pollution data. }\end{array}$ & $\begin{array}{l}\text { Increasing exposure to } \mathrm{PM}_{10} \text { and } \mathrm{NO}_{2} \text { independently } \\
\text { associated with reduced serum IgM responses to } P \text {. jirovecii } \\
\text { Msg. }\end{array}$ \\
\hline $\begin{array}{l}\text { Alvaro-Meca, } \\
\text { et al } \\
{[40]}\end{array}$ & 2015 & Spain & $\begin{array}{l}\text { National study of hospitalized HIV-positive } \\
\text { patients with PCP. Climatologic and air } \\
\text { pollution data. }\end{array}$ & $\begin{array}{l}\text { Higher concentrations of } \mathrm{NO}_{2}, \mathrm{PM}_{10}, \mathrm{CO} \text {, and ozone } \\
\text { associated with increased likelihood of hospitalization with } \\
\text { PCP. }\end{array}$ \\
\hline $\begin{array}{l}\text { Blount, et al } \\
{[43]}\end{array}$ & 2017 & $\begin{array}{l}\text { San } \\
\text { Francisco, } \\
\text { USA }\end{array}$ & $\begin{array}{l}\text { Single center prospective cohort study. } \\
\text { Climatologic and air pollution data. }\end{array}$ & $\begin{array}{l}\text { Increasing exposure to ozone associated with reduced } \mathrm{BAL} \\
\text { fluid IgA responses to } P \text {. jirovecii } \mathrm{Msg} \text {, and } \mathrm{NO}_{2} \text { independently } \\
\text { associated with increased } \mathrm{BAL} \text { fluid } \operatorname{lgA} \text { responses to } P \text {. } \\
\text { jirovecii Msg. }\end{array}$ \\
\hline
\end{tabular}

Key: $\mathrm{HIV}=$ human immunodeficiency virus; $\mathrm{PCP}=$ Pneumocystis pneumonia; $\mathrm{SO}_{2}=$ sufur dioxide; $\mathrm{CO}=$ carbon monoxide; $\mathrm{NO}_{2}=$ nitrogen dioxide; $\mathrm{PM}_{10}$

$=$ particulate matter $<10 \mu \mathrm{m}$ in diameter; Msg = major surface glycoprotein; BAL = Bronchoalveolar lavage.




\section{Discussion}

We believe that the present study is the first systematic review of the relationship between Pneumocystis infection in its animal and human hosts, and the effects of climatological and air pollution factors in the environment on this relationship. This review found evidence of associations between Pneumocystis infection in animal and human hosts, and climatological and environmental air pollution factors, but the quality of evidence was poor and was limited by inconsistent and incomplete sampling methodology in both animal and human studies.

\subsection{Non-Pneumocystis Fungi - Seasonal and Climatological Factors}

Climatological factors, including temperature and humidity, are associated with variations in concentrations of ascomycetes, basidiomycetes, and other fungi in air [44-48]. A study from Porto Alegre, Southern Brazil, showed the highest detection of airborne fungal spores was in summer (December-February), when average minimum air temperatures are typically between 18 and $21^{\circ} \mathrm{C}$ [7]. The lowest rates of detection were in the autumn (March-May), when average minimum temperatures are typically between 12 and $17^{\circ} \mathrm{C}$ [45]. A second study from Fortaleza, North East Brazil, where the climate is hotter, reported seasonal variation in rates of detection of airborne fungi, (higher rates of detection were observed in January-April, and lower rates were recorded in July-October [46]. This city experiences a rainy season (February-July: rainfall $1883.5 \mathrm{~mm}$, average temperature $26.8^{\circ} \mathrm{C}$ ) and a dry season (August-January: rainfall $260 \mathrm{~mm}$, average temperature $\left.27.6^{\circ} \mathrm{C}\right)[46]$.

\subsection{Pneumocystis - Seasonal Factors - Average Temperature}

In the studies of Pneumocystis in animals studied in the wild, in slaughterhouses, and in research laboratories that were identified in this systematic review interpretation of the observed seasonal variation is confounded by the fact that none of the studies systematically sampled throughout the year, nor sampled in consecutive years, and none of the studies included "controls". Thus, possible alternative explanations for the apparent seasonal variation must include closer animal-to-animal proximity within animal colonies, driven by climatological factors, and by season, for example by closer co-habitation during the mating season for an individual animal host. This potentially increases the chance for airborne or "other" animal-to-animal transmission, and thus likelihood of detection by opportunistic, or systematic sampling. In the studies of pigs, another factor influencing detection of Pneumocystis is the type of husbandry used in rearing the animals, as higher rates of detection were observed in semi-intensively farmed animals when compared with pigs who were intensively-farmed. This finding has been ascribed to less control of production variables in pigs reared semi-intensively [17]. Additionally, detection of Pneumocystis has been associated with underlying viral and/or bacterial infection in pigs. It has been suggested that these infections may act as potential "immune suppressants" thus permitting colonization/infection with Pneumocystis $[15,17]$

Taken together the human studies clearly demonstrate evidence of a seasonal and/or climatological association and presentation with PCP, or serologic or autopsy detection of infection. A seasonal variation in incidence of PCP was first reported in 1991 [19]. Subsequently, the relationship between seasonality and temperature and hospitalization with PCP has described 
inconsistent findings with some, but not all studies describing any association. In both HIVinfected and uninfected patients the risk of PCP has been observed to be higher in summer (London, UK) [28, 35], (Geneva, Switzerland [29] (Munich, Germany) [36] and (San Francisco, USA) [6] autumn (Melbourne, Australia) [41], and winter (Seville, Spain) [40]. As previously suggested [6], these differing results might be as a result of differences in patient populations, climatological factors, geography, Pneumocystis genotypes, or to differences in study design [6]. Because of geographical climatological differences, it is likely that summer temperatures in one country, or region, are similar to autumn or winter temperatures in another geographical location. For example, in Spain winters are generally mild (most regions having an average temperature between 10 and $20^{\circ} \mathrm{C}$ ), and summers are hot (with average temperatures greater than $30^{\circ} \mathrm{C}$ ) [40]. Thus, the average temperature in a Spanish winter is similar to that observed in other seasons in other countries during which the highest incidence of PCP has been described [40]. In London the "peak" summer temperature was $13^{\circ} \mathrm{C}$ [28], the mean summer temperature in San Francisco was $17.6^{\circ} \mathrm{C}$ [6], and average temperature in Melbourne was between 13.2 and $20^{\circ} \mathrm{C}[7,40]$. Taken together, interpretation of these data, infer that rather than a seasonal association, presentation with PCP appears to be highest during the season of the year when the average temperature is between 10 and $20^{\circ} \mathrm{C}$ [40]. As previously noted [40], among HIV-infected persons, other confounding factors, including tobacco smoking [24], chronic obstructive pulmonary disease, bacterial pneumonia, and colonization of the respiratory tract by $P$. jirovecii, can contribute to increased risk of developing $\mathrm{PCP}$, and also that these contributing factors additionally, are potentially affected by climatological factors [24].

A similar seasonal association is apparent in the two studies of infants done in Chile [25, 26]. In the autopsy study the highest rate of detection of Pneumocystis was in winter (June-August), when average maximum temperatures were $16-18^{\circ} \mathrm{C}$, and the lowest rate of detection was in autumn (March-May), when average maximum temperatures were $20-28^{\circ} \mathrm{C}[7,25]$. In the study of serum antibody responses to Pneumocystis MsgA constructs among immune competent infants the lowest peaks were also detected in autumn (March-May) [26].

\subsection{Seasonal Factors - Humidity and Precipitation}

There is a less certain association between the climatological variables of humidity and precipitation, and detection of Pneumocystis in animal and human hosts, or with presentation with PCP in humans. Some animal studies $[12,17,18]$ and some human studies $[20,27,28,33]$ suggest an association, but others do not. Confounding these observations is the fact that data about this climatological variable was not routinely collected in either the animal or human studies.

A further potential factor, confounding interpretation of data concerning both temperature and humidity/precipitation in humans is that in the EuroSIDA study, which was a prospective observational cohort study that reported diagnosis of PCP in North, Central, and South Europe, the higher prevalence of PCP described in cooler, wetter North European climates might be explained by other logistical factors, including better access to healthcare (and so the likelihood of being diagnosed with PCP) in North Europe [30]. A similar interpretation can be applied to the findings from another European retrospective multicenter study [31]. 


\subsection{Seasonal Factors - Outdoor Activities}

The study from Atlanta, USA showed spending time outdoors gardening, camping or hiking in the six months prior to hospitalization with pneumonia was strongly associated with risk of PCP [21]. Additionally, studies from Cincinnati and San Francisco, USA showed clustering of PCP by Zip Codes [22, 24]: the former study showing more cases in affluent areas with more green space [22], the latter reporting more cases in residential areas containing parks and small yards [24]. Taken together, these three studies infer that susceptible individuals are at greater risk of developing PCP if they have increased opportunities for being outdoors, and thus possibly for increased environmental exposure to Pneumocystis.

\subsection{Genetic Factors}

Observations from national (Netherlands) and single-site London (UK) cohorts infer that there might be an ethnic/genetically-determined predisposition to development of PCP [32, 37]. Single point mutations (SNPs) in genes associated with innate immune function are increasingly recognized as significant factors dictating an individual's susceptibility to infection [49-51]. Two reports describe an association between SNPS and development of PCP in HIV-infected individuals $[52,53]$. The Fcylla receptor, which binds to immune complexes to facilitate uptake of microbes, is encoded by a gene with synonymous (functional) polymorphisms that affects binding affinity to IgG. Participants in the Multicenter AIDS Cohort Study (MACS) with the FcyRlla RR genotype progressed to AIDS (i.e., CD4 count $<200$ cells/uL) faster than participants with $\mathrm{RH}$ or $\mathrm{HH}$ genotypes [52]. By contrast, participants with an FcyRlla HH genotype progressed more quickly to AIDS (defined by development of PCP) than those with other genotypes [52]. While the underpinning mechanisms remain uncertain, these results raise intriguing questions about the antibodies that opsonize Pneumocystis and interact with FcyRlla receptors. The chemokine receptor CXCR6 is a co-receptor that facilitates fusion of HIV to CD4 cells. The ligand for CXCR6 (CCXCL16) is highly expressed in the lungs. A SNP in codon 3 (CXCR6-E3K) is common in African Americans and rare in Caucasians. The AIDS Link to Intravenous Experience (ALIVE) study, a prospective cohort study of predominantly African American HIV-infected drug users, examined the relationship of CXCR6 SNPs and development of PCP [53]. Time to development of PCP was similar among the genotypes, but subjects homozygous or heterozygous for CXCR6-3E were more likely to die after PCP (and thus had a shorter survival time) than subjects homozygous for CXCR6$3 \mathrm{~K}[53]$.

The current epidemiology of pediatric PCP in the USA demonstrates that it is less frequently observed in HIV-infected children. By contrast cases associated with hematologic malignancy and primary immunodeficiency have become more prominent, infants being the most commonly affected [54]. Well-described mutations in MHC class II (bare lymphocyte syndrome), recombination activating genes (RAG) -1 and -2 , signal transducer and activator of transcription (STAT) -3 , and IL-21R that can be modeled in genetically engineered mice and $P$. murina infection, provide evidence of genetic susceptibility to Pneumocystis infection [55]. Taken together these data suggest a gene-environment interaction in the disease. 


\subsection{Air Pollution}

Among the general population it is increasingly evident that ambient air pollution contributes to the global burden of respiratory disease, including asthma, Chronic Obstructive Pulmonary Disease, and pneumonia [56-65]. The studies identified in this systematic review originating from Spain and San Francisco, USA clearly demonstrate an association between ambient air pollution factors and presentation of HIV-infected adults with PCP $[6,40]$. It is intriguing that in one study there was no association with $\mathrm{PM}_{10}, \mathrm{NO}_{2}, \mathrm{CO}$, or ozone, and an association was only evident for $\mathrm{SO}_{2}$ [6]. In the other study $\mathrm{NO}_{2}, \mathrm{PM}_{10}, \mathrm{CO}$, and ozone were associated with risk of hospitalization with PCP [40]. This apparent difference may in part be explained by the fact that San Francisco is one of the least polluted cities in the United States and so it is possible that levels of these pollutants were below thresholds that can trigger respiratory complications [6].

The mechanisms by which ambient air pollution increases susceptibility to pulmonary infection are not well defined. Controlled exposure studies of single pollutants that have used cells, animals and human subjects indicate that ambient air pollutants alter innate lung immunity at multiple levels, including altered muco-ciliary function, respiratory epithelial cell dysfunction, impaired alveolar macrophage phagocytosis, and dysfunction of surfactant protein A and D [Reviewed in 6]. However, the effects of ambient air pollution factors on humoral immunity and serologic responses to pulmonary infection, and the immune-toxic effects of real-life exposures to ambient air pollution factors are poorly understood. In one study from San Francisco [42] $\mathrm{PM}_{10}$ and $\mathrm{NO}_{2}$ were independently associated with suppressed IgM (but not $\lg \mathrm{G}$ ) responses to Pneumocystis Msg constructs. It was suggested that $\mathrm{PM}_{10}$ particles encountering bronchus associated lymphoid tissue, might impair antigen presenting cell function, resulting in decreased activation of the humoral immune system and suppressed serologic responses [42]. Both animal and human exposure studies have found mixed effects of $\mathrm{NO}_{2}$ inhalation on bronchoalveolar and systemic antibody responses [66-69]. In a second study also from San Francisco patients with PCP increasing exposure to ozone was associated with reduced BAL fluid IgA responses to $P$. jirovecii Msg constructs and increasing exposure to $\mathrm{NO}_{2}$ was independently associated with increased BAL fluid IgA responses to $P$. jirovecii Msg [43]. These results might be explained by the observation that ozone is a potent oxidant resulting in both bronchoalveolar, and systemic inflammation. Animal studies have found that rats in the first two weeks of exposure to ozone demonstrate decreased antibody responses to microbial antigens such as Listeria spp [70].

\section{Conclusions}

This systematic review found evidence of associations between Pneumocystis infection in both animal and human hosts, and climatological and environmental air pollution factors. These data are limited by inconsistent and incomplete sampling methodology in both animal and human studies. Data from human studies infer that rather than a seasonal association, presentation with PCP appears to be highest when the average temperature is between 10 and $20^{\circ} \mathrm{C}$. A potential confounder is possible genetically-determined predisposition to, or protection from infection. There is evidence of an association with hospitalization with PCP and ambient air pollution factors, as well as a clear effect of air pollution on both systemic and bronchoscopic lavage fluid humoral responses to Pneumocystis. The results of this systematic review provide an improved 
understanding of the conditions involved in transmission of Pneumocystis in both animal and human hosts. Such knowledge is critical to efforts aimed at prevention of infection.

\section{Acknowledgments}

We thank Professor Olga Matos and Dr Christiana Weissenbacher-Lang, for helpful discussions about their publications. Both provided additional data that was not included in their original publications. Additionally, Professor Matos provided us with climatological data (temperature, humidity and precipitation) which was obtained from the Portuguese Weather Institute.

\section{Author Contributions}

Developed the concept for this article: PDW; performed the literature search: LH \& RFM; wrote the manuscript: RFM; critically reviewed drafts of the manuscript for intellectual content, and approved the final submitted manuscript: PDW, LH, RFM.

\section{Funding}

PDW and RFM received no funding for this work. LH was funded by NIH K24 HL087713 and NIH R01 HL128156.

\section{Competing Interests}

The authors have declared that no competing interests exist.

\section{References}

1. Miller RF, Smulian AG, Walzer PD. Pneumocystis species. Chapter 269 in: Mandell, Douglas, and Bennett's Principles and Practise of Infectious Diseases: $9^{\text {th }}$ Edition. Editors: GL Mandell, JE Bennett, and R Dolin. Elsevier Science. 2018 (in press).

2. Brown GD, Denning D, Gow NA, Levitz SM, Neta MG, White TG. Hidden killers: human fungal infections. Sci Transl Med. 2012; 4: 165rv13.

3. Schildgen V, Mai S, Khalfaoui S, Lüsebrink J, Pieper M, Tillmann RL, et al. Pneumocystis jirovecii can be productively cultured in differentiated CuFi8 airway cells. MBio. 2014; 5: e01186-14.5.

4. Cushion MT, Linke MJ, Ashbaugh A, Sesterhenn T, C-ollins MS, Lynch K, et al. Echinocandin treatment of Pneumocystis pneumonia in rodent models depletes cysts leaving trophic burdens that cannot transmit the infection. PLoS One. 2010; 29: e8524.

5. Yiannakis EP, Boswell TC. Systematic review of outbreaks of Pneumocystis jirovecii pneumonia: evidence that $P$. jirovecii is a transmissible organism and the implications for healthcare infection control. J Hosp Infect. 2016; 93: 1-8.

6. Djawe K, Levin L, Swartzman A, Fong S. Roth B, Grieco K et al. Environmental risk factors for Pneumocystis pneumonia hospitalizations in HIV patients. Clin Infect Dis. 2013; 56: 74-81.

7. World Weather Online: https://www.worldweatheroneline.com [Accessed 02 August 2018].

8. Šebek Z, Rosický B. The finding of Pneumocystis carinii in shrews (Insectivora: Soricidae). Folia Parasitologica. 1967; 14: 263-267. 
9. Poelma FG, Broekhuizen S. Pneumocystis carinii in hares, Lepus europaeus Pallas, in The Netherlands. Z Parasitenk. 1972; 40: 195-202.

10. Shiota T, Kurimoto H, Yoshida Y. Prevalence of Pneumocystis carinii in wild rodents in Japan. Zentralbl Bakteriol Mikrobiol Hyg A. 1986; 261: 381-389.

11. Laakkonen J, Henttonen H, Niemimaa J, Soveri T. Seasonal dynamics of Pneumocystis carinii in field vole, Microtus agrestis, and common shrew, Sorex araneus, in Finland. Parasitol. 1999; 118: 1-5.

12. Demanche C, Wanert F, Herrenschmidt N, Moussu C, Durand-Joly I, Dei-Cas E, et al. Influence of climatic factors on Pneumocystis carriage within a socially organized group of immunocompetent macaques (Macaca fascicularis). J Eukaryot Microbiol. 2003; 50: 611-613.

13. Icenhour CR, Arnold J, Medvedovic M, Cushion MT. Competitive coexistence of two Pneumocystis species. Infect Genet Evol. 2005; 6: 177-186.

14. Sanches EM, Pascador C, Rozza D, Ravazzolo AP, Driemiers D, Ravazzolo AP, et al. Detection of Pneumocystis spp. in lung samples from pigs in Brazil. Med Mycol. 2007; 45: 395-399.

15. Kim KS, Jung JY, Kim JH, Kang S-C, Hwang E-K, Park B-K, et al. Epidemiological characteristics of pulmonary pneumocystosis and current infections in pigs in Jeju Island, Korea. J Vet Sci. 2011; 12: 15-19

16. Akbar H, Pinçon C, Aliouat-Denis C-M, Derouiche S, Taylor M-L, Pottier M, et al. Characterizing Pneumocystis in the lungs of bats: understanding Pneumocystis evolution and the spread of Pneumocystis organisms in mammal populations. Appl Environ Microbiol. 2012; 78: 81228136.

17. Esgalhado R, Esteves F, Antunes F, Matos O. Study of the epidemiology of Pneumocystis carinii f. sp. suis in abattoir swine in Portugal. Med Mycol. 2013; 51: 66-71.

18. Weissenbacher-Lang C, Kureljušić B, Nedorost N, Matula B, Schiessl W, Stienberger D, et al. Retrospective analysis of bacterial and viral co-infections in Pneumocystis spp. positive lung samples of Austrian pigs with pneumonia. PLoS One. 2016; 11: e0158479.

19. Hoover DR, Graham NM, Bacellar H, Schrager LK, Kaslow R, Visscher B, et al. Epidemiologic patterns of upper respiratory illness and Pneumocystis carinii pneumonia in homosexual men. Am Rev Respir Dis. 1991; 44: 756-759.

20. Baccetti P. Seasonal and other influences on United States AIDS incidence. Stat Med. 1994; 13 : 1921-1931.

21. Navin TR, Rimland D, Lennox JL, Jernigan J, Cetron M, Hightower A, et al. Risk factors for community-acquired pneumonia among persons infected with the human immunodeficiency virus. J Infect Dis. 2000: 181: 158-164.

22. Dohn MN, White ML, Vigdorth EM, Buncher CR, Hertzberg VS, Baughman RP, et al. Geographic clustering of Pneumocystis carinii in patients with HIV infection. Am J Resp Crit Care Med. 2000; 162: 1617-1621.

23. Morris AM, Swanson M, Ha H, Huang L. Geographic distribution of human immunodeficiency virus-associated Pneumocystis carinii pneumonia in San Francisco. Am J Respir Crit Care Med. 2000; 162: 1622-1626.

24. Morris A. Kingsley LA, Groner G, Lebedeva IP, Beard CB, Norris KA. Prevalence and clinical predictors of Pneumocystis colonization among HIV-infected men. AIDS. 2004; 18: 793-798. 
25. Vargas SL, Ponce CA, Luchsinger V, Silva C, Gallo M, Lopez R, et al. Detection of Pneumocystis carinii f. sp. hominis and viruses in presumably immunocompetent infants who died in the hospital or in the community. J Infect Dis. 2005; 191: 122-126.

26. Djawe K, Daly KR, Vargas SL, Santolaya ME, Ponce CA, Bustamante RM, et al. Seroepidemiological study of Pneumocystis jirovecii infection in healthy infants in Chile using recombinant fragments of the $P$. jirovecii major surface glycoprotein. Int J Infect Dis. 2010: 14: e1060-1066.

27. Settnes OP, Genner J. Pneumocystis carinii in human lungs at autopsy. Scand J Infect Dis. 1986; 18: 489-496.

28. Miller RF, Grant AD, Foley NM. Pneumocystis carinii pneumonia. Lancet. 1992; 339: 747-748.

29. Vanhems $P$, Hirschel B, Morabia A. Seasonal incidence of Pneumocystis carinii pneumonia. Lancet. 1992; 339: 1182.

30. Lundgren JD, Barton SE, Lazzarin A, Danner S, Goebel FD, Pehrson P, et al. Factors associated with the development of Pneumocystis carinii pneumonia in 5,025 European patients with AIDS. Clin Infect Dis. 1995; 21: 106-113.

31. Delmas M-C, Schwoebel V, Heisterkamp SH, Downs AM, Ancelle-Park RA, Brunet JB, et al. Recent trends in Pneumocystis carinii pneumonia as AIDS-defining disease in nine European countries. J Acquir Immune Defic Syndr. 1995; 9: 74-80.

32. Del Amo J, Petruckevitch A, Phillips AN, Johnson AM, Stephenson J, Desmond N, et al. Spectrum of disease in Africans with AIDS in London. AIDS. 1996; 10: 1563-1569.

33. Lubis N, Baylis D, Short A, Stebbing J, Teague A, Portsomuth S, et al. Prospective cohort study showing changes in the monthly incidence of Pneumocystis carinii pneumonia. Postgrad Med J. 2003; 79: 164-166.

34. Miller RF, Evans HE, Copas AJ, Cassell JA. Climate and genotypes of Pneumocystis jirovecii. Clin Microbiol Infect. 2007; 13: 445-448.

35. Walzer PD, Evans HER, Copas AJ, Edwards SG, Grant AD, Miller RF. Early predictors of mortality from Pneumocystis jirovecii pneumonia in HIV-infected patients. Clin Infect Dis. 2008; 46: 625-633.

36. Sing A, Schmoldt S, Laubender RP, Heesemann J, Sing D, Wildner M. Seasonal variation of Pneumocystis jirovecii infection: analysis of underlying climactic factors. Clin Microbiol Infect. 2009; 15: 957-960.

37. Schoffelen AF, van Lelyveld SF, Barth RE, Gras L, de Wolf F, Netea MG, et al; ATHENA national observational cohort study Lower incidence of Pneumocystis jirovecii pneumonia among Africans in the Netherlands host or environmental factors? AIDS. 2013, 27: 1179-1184.

38. Varela JM, Regordán C, Medrano FJ, Respaldiza N, de la Hora C, Montes-Cano MA, et al. Climatic factors and Pneumocystis jirovecii infection in southern Spain. Clin Microbiol Infect. 2004; 10: 770-772.

39. Calderón EJ, Varela JM, Medrano FJ, Nieto V, Gonzalez-Becarra C, Respaldiza N, et al. Epidemiology of Pneumocystis carinii pneumonia in southern Spain. Clin Microbiol Infect. 2004; 10: 673-676.

40. Alvaro-Meca A, Palomares-Sancho I, Diaz A, Resino R, De Miguel AG, Resino S. Pneumocystis pneumonia in HIV-positive patients in Spain: epidemiology and environmental risk factors. J Int AIDS Soc. 2015; 18: 19906. 
41. Tadros S, Teichtahl AJ, Cicirello S, Wicks IP. Pneumocystis jirovecii pneumonia in systemic autoimmune rheumatic disease: a case-control study. Semin Arthritis Rheum. 2017; 46: 804809.

42. Blount RJ, Djawe K, Daly KR, Jarlsberg LG, Fong S, Balmes J, et al. Ambient air pollution associated with suppressed serologic responses to Pneumocystis jirovecii in a prospective cohort of HIV-infected patients with Pneumocystis pneumonia. PLoS One. 2013; 8: e80795.

43. Blount RJ, Daly KR, Fong S, Chang E, Greico K, Greene M, et al. Effects of clinical and environmental factors on bronchoalveolar antibody responses to Pneumocystis jirovecii: a prospective cohort study of HIV+ patients. PLoS One. 2017; 12: e0180212.

44. Bush RK. Aerobiology of pollen and fungal allergens. J Allergy Clin Immunol 1989; 84: 1120-44.

45. Mezzari A, Perin C, Santos SA, Bernd LA. Airborne fungi in the city of Porto Alegre, Rio Grande do Sul, Brazil. Rev Inst Med Trop Sao Paulo. 2002; 44: 269-272.

46. Menzes EA, Trindade EC, Costa MM, Freire CC, Calvalcante MdeS, Cunha FA. Airborne fungi isolated from Fortaleza city, state of Ceará, Brazil. Rev Inst Med Top S Paulo. 2004; 46: 133137.

47. Favero-Longo SE, Sandrone S, Matteucci E, Appolonia L, Piervittori R. Spores of lichen-forming fungi in the mycoaerosol and their relationships with climate factors. Sci Total Environ. 2014; 466-7: 26-33.

48. Grinn-Gofron A, Strzelczak A, Przestrzelska K. Seasonal variation of Ganoderma spore concentrations in urban and suburban districts of the city of Szczecin, Poland. Ann Agric Environ Med. 2015; 22: 6-10.

49. Lupiañez CB, Canet LM, Carvalho A, Alcazar-Fuoli L, Springer J, Lackner M, et al. Polymorphisms in host immunity-modulating genes and risk of invasive aspergillosis: results from the AspBIOmics consortium. Infect Immun. 2015; 84: 643-657.

50. Salas A, Pardo-Seco J, Barral-Arca R, Cebey-Lopez M, Gomez-Carballa A, Rivero-Calle I, et al; GENDRES Network. Whole exome sequencing identifies new host genomic susceptibility factors in empyema caused by Streptococcus pneumoniae in children: a pilot study. Genes (Basel). 2018; 9. pii: E240.

51. Kondoh $T$, Letko $M$, Munster VJ, Manzoor R, Maruyama J, Furuyama $W$, et al. Single nucleotide polymorphisms in human NPC1 influence filovirus entry into cells. J Infect Dis. $2018 \mathrm{Jul}$ 14. [Epub ahead of print]

52. Forthal DN, Landucci G, Bream J, Jacobson LP, Phan TB, Montoya B. FcyRlla genotype predicts progression of HIV infection. J Immunol. 2007; 179: 7916-7923.

53. Duggal $P, A n P$, Beaty $T H$, Strathdee $S A$, Farzadagen $H$, Markham RB, et al. Genetic influence of CXCR6 chemokine receptor alleles on PCP-mediated AIDS progression among African Americans. Gen Immun. 2003; 4: 245-250.

54. Inagaki K, Blackshear C, Hobbs CV. Pneumocystis infection in children: National trends and characteristics in the United States, 1997-2012. Pediatr Infect Dis J. 2018 May 21. [Epub ahead of print].

55. Elsegeiny W, Zheng M, Eddens T, Gallo RL, Dai G, Trevejo-Nunez G, et al. Murine models of Pneumocystis infection recapitulate human primary immune disorders. JCI Insight. 2018; 3: e91894.

56. Lim SS, Vos T, Flaxman AD, Danael G, Shibuya K, Adair-Rohani H, et al. A comparative risk assessment of burden of disease and injury attributable to 67 risk factors and risk factor 
clusters in 21 regions, 1990-2010: a systematic analysis for the global burden of disease study 2010. Lancet. 2012; 380: 2224-2260.

57. Laumbach RJ, Kipen HM. Respiratory health effects of air pollution: update on biomass smoke and traffic pollution. J Allergy Clin Immunol. 2012; 129: 3-11.

58. Xiao Q, Liu Y, Mulholland JA, Russell AG, Darrow LA, Tolbert PE, et al. Pediatric emergency department visits and ambient air pollution in the US State of Georgia: a case-crossover study. Environ Health. 2016; 15: 115.

59. Neupane B, Jerrett M, Burnett RT, Marrie T, Arain A, Loeb M. Long-term exposure to ambient air pollution and risk of hospitalization with community-acquired pneumonia in older adults. Am J Respir Crit Care Med. 2010; 181: 47-53.

60. Cheng $\mathrm{M}-\mathrm{H}$, Chiu $\mathrm{H}-\mathrm{F}$, Yang $\mathrm{C}-\mathrm{Y}$. Coarse particulate air pollution associated with increased risk of hospital admissions for respiratory diseases in a tropical city, Kaohsiung, Taiwan. Int J Environ Res Public Health. 2015; 12: 13053-13068.

61. Pirozzi CS, Jones BE, VanDerslice JA, Zhang Y, Paine R, Dean NC. Short-term air pollution and incident pneumonia. A case-crossover study. Ann Am Thorac Soc. 2018; 15: 449-459.

62. Li D, Wang JB, Zhang ZY, Shen P, Zheng PW, Jin MJ, et al. Effects of air pollution on hospital visits for pneumonia in children: a two-year analysis from China. Environ Sci Pollut Res Int. 2018; 25: 10049-10057.

63. Medina-Ramon M, Zanobetti A, Schwartz J. The effect of ozone and PM10 on hospital admissions for pneumonia and chronic obstructive pulmonary disease: a national multicity study. Am J Epidemiol. 2006; 163: 579-588.

64. Kim CS, Alexis NE, Rappold AG, Kehrl H, Hazucha MJ, Lay JC, et al. Lung function and inflammatory responses in healthy young adults exposed to $0.06 \mathrm{ppm}$ ozone for 6.6 hours. Am J Respir Crit Care Med. 2011; 183: 1215-1221.

65. Arjomandi M, Wong H, Donde A, Frelinger J, Dalton S, Ching W, et al. Exposure to medium and high ambient levels of ozone causes adverse systemic inflammatory and cardiac autonomic effects. Am J Physiol Heart Circ Physiol. 2015; 308: 1499-1509.

66. Ehrlich R, Silverstein E, Maigetter R, Fenters JD. Immunologic response in vaccinated mice during long-term exposure to nitrogen dioxide. Environ Res. 1975; 10: 217-223.

67. Fujimaki $H$, Shimizu F, Kubota K. Suppression of antibody response in mice by acute exposure to nitrogen dioxide: in vitro study. Environ Res. 1981; 26: 490-496.

68. Balchum OJ, Buckley RD, Sherwin R, Gardner M. Nitrogen dioxide inhalation and lung antibodies. Arch Environ Health. 1965; 10: 274-277.

69. Hidekazu F, Fujio S. Effects of acute exposure to nitrogen dioxide on primary antibody response. Arch Environ Health. 1981; 36: 114-119.

70. Jakab GJ, Spannhake EW, Canning BJ, Kleeberger SR, Gilmour MI. The effects of ozone on immune function. Environ Health Perspect. 1995; 103 Suppl 2: 77-89. 


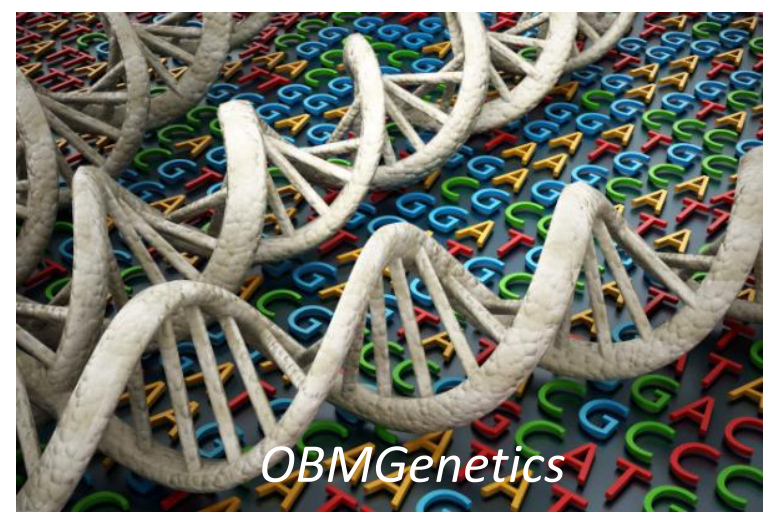

Enjoy OBM Genetics by:

1. Submitting a manuscript

2. Joining in volunteer reviewer bank

3. Joining Editorial Board

4. Guest editing a special issue

For more details, please visit:

http://www.lidsen.com/journals/genetics 